\title{
Financial Risks of Constituents of the Russian Federation
}

\author{
Sabitova Nadia \\ Kazan Federal University, Institute of Management, Economics and Finance, Kazan, 420008, Russia \\ Email: sabitovanm@mail.ru \\ Shavaleyeva Chulpan
}

Kazan Federal University, Institute of Management, Economics and Finance, Kazan, 420008, Russia

\section{Doi:10.5901/mjss.2014.v5n24p209}

\begin{abstract}
The Russian Federation comprises of 83 constituents which vary not only in territory, climate zones, resource endowment, but also in economic indicators which have influence on their investment attractiveness. While making decisions of investment, investors make allowances for investment attractiveness of regions and assess financial risks. Comparative analysis of ratings of constituents of the Russian Federation according to valuations of international and Russian rating agencies, as well as of the Ministry of Regional Development of the Russian Federation and the Ministry of Finance of the Russian Federation is presented in this study. It has been identified that only international rating agencies and some Russian rating agencies assess risks. Besides, many rating agencies do not have indicators of evaluation of non-systemic risks in their system of estimated figures of investment attractiveness of regions. The authors propose to include these indicators into estimated figures of investment attractiveness of constituents of the Russian Federation.
\end{abstract}

Keywords: Constituents of the Russian Federation; rating agencies; investment attractiveness; financial risks; systemic risks; nonsystemic risks

\section{Introduction}

In the process of selecting investment objects in Russia, investors examine not only projects and risks specific to these projects, but also a constituent of the Russian Federation where this object is located considering attractiveness and risks of investment in this constituent. Investment attractiveness of constituents of the Russian Federation varies enormously. Primarily it is connected with current territorial position, environment conditions, industrial structure differentiation formed over the years, which have influence on economic strength of regions. The Russian Federation as the federal state comprises of constituents distinguished by their statuses. It is composed of 83 constituents which were predominantly formed during the soviet period; 21 of them have statuses of republics, there are also 9 territories, 46 regions, 2 cities of federal importance, 1 autonomous region, and 4 autonomous districts. The said constituents of the Russian Federation vary in sizes of territory and number of population. Thus, statistics shows that as of January 1, 2013, the largest territories belong to: the Sakha (Yakutia) Republic (3,083.5 thousand sq. km, population is 956 thousand people), the Krasnoyarsk Territory (2.366,8 thousand sq. $\mathrm{km}$, population is 2,838 thousand people), the Tyumen Region (1,464.2 thousand sq. $\mathrm{km}$, population is 3,480 thousand people). The smallest territories belong to: the Republic of Ingushetia (3.6 thousand sq. km, population is 430 thousand people), the Republic of Adygea (7.8 thousand sq. km, population is 443 thousand people), the Republic of North Ossetia (8.0 thousand sq. km, population is 709 thousand people). In addition to the above Russian regions have different economic strength and accordingly different investment climate, and it has influence on financial risks. For example, volume of gross regional product of constituents of the Russian Federation with the biggest and the smallest indicator values (Moscow and the Republic of Ingushetia) differs by 384-fold. Even if we put Moscow aside, the scatter will remain significant; for instance, indicators of the Moscow Region and the Republic of Ingushetia differ in 86fold, and they differ in 49-fold we compare the Moscow Region with the Republic of Tatarstan. The scatter is significant for other economic indicators. It is very hard to select a constituent of the Russian Federation for investing under these circumstances. That is why it is essential to analyze current ratings given by international and Russian rating agencies, as well as ratings of other organizations for the purpose of their comparison. 


\section{Analysis of Primary Publications}

Scientific literature pays considerable attention to the issue of financial risks, for example Hommel U., M. Frenkel, M. Rudolf [1] But most of the studies are devoted to the examination of corporate risks. Particularly, studies of such authors as Paudyn, B. which learned the problem of budgetary health assessment by credit rating agencies [2], Li, C., C. Balding and M. Lee explored an influence of political risk on the public finance [3], Arnold, B., C. Borio, L. Ellis and F. Moshirian in their research paper analized various issues that need to be tackled when promoting financial stability, reviewing the progress made in certain key areas and the remaining challenges [4]. Less attention is paid to issues of financial risks in public sector, though this aspect of financial risks is illustrated in studies of R. Musgrave [5] and other researchers. But to our opinion not enough attention is paid to issues of evaluation of financial risks of constituents of the Federation in federal states, and especially in Russia.

\section{Research Objective}

To examine investment attractiveness of constituents of the Russian Federation in terms of comparison of ratings of international and Russian rating agencies, as well as the Ministry of Regional Development of the Russian Federation and the Ministry of Finance of the Russian Federation, and evidentiate availability of indicators of evaluation of systemic and non-systemic risks.

\section{Key Findings}

The Russian Federation and particularly its constituents are interested in attracting investments. First of all it is important to note that size and population of considerable part of constituents of the Russian Federation are larger than some European countries. According to the Constitution of the Russian Federation they have status of fully legitimate and independent economic entities. All of them shall be interested in development of their regions and accordingly apply efforts for building economic relations with other regions, attraction of investors including foreign investors either. Investors may diversify into private sector and public sector projects. In the first case investors are concerned about general economic and investment climate in the region, and accordingly about general risk. In the second case investors are concerned about trust in public authorities of this constituents of the Russian Federation, and accordingly about risk. That is why we suppose that risks of the public sector can also be divided in systemic and non-systemic.

Rating agencies are engaged in evaluation of attractiveness and risks of different economic entities including credit risks of public-law entities. That is why when investors select a region for investment, they may be guided by ratings assigned to constituents of the Russian Federation by rating agencies. The Ministry of Finance of the Russian Federation has included Fitch Ratings, Standard \& Poor's, Moody's Investors Service into the register of accredited rating agencies. Such Russian rating agencies as Expert, AC\&M (Analysis, Consultations and Marketing), Rus-Rating NRA (National Rating Agency) are also included in this register. The Ministry of Regional Development of Russia, as well as such magazines as Director General, public opinion foundations, etc. also makes independent assessment of development of constituents of the Russian Federation. The Ministry of Finance of the Russian Federation assesses regional financial management quality. All these data can be a basis for making financial decisions of investment in one or another region.

Foreign rating agencies assign credit ratings to regions upon respective request. Request to one of international rating agencies is an exclusive requirement of the Bank of Russia which is necessary for issuance of securities and their allocation in the Lombard List (Directive of the Central Bank \#2861-U dated August 10, 2012). Decision about putting the Bank of Russia on the Lombard List is made by the Board of Directors of the Bank of Russia including and with due regard to one of the following rating agencies: Fitch Ratings, Standard \& Poor's, Moody's Investors Service. But in a number of instances some constituents of the Russian Federation address international rating agencies even in the absence of issuance of regional securities. We can exemplify it by the Republic of Tatarstan which has not effected issuance of regional securities, but it has ratings of international rating agencies. Thus, in January 2014, international rating agency Fitch Ratings confirmed long-term foreign and local currency issuer default rating (IDR) of the Republic of Tatarstan of the Russian Federation at BBB and short-term foreign currency IDR at F3. National long-term rating has been confirmed at the rate of AAA(rus). Long-term rating outlook was considered as sustainable. In this case the Republic of Tatarstan needs these international ratings for presenting the republic as a region with congenial investment climate.

When international rating agencies assess regions, they do not disclose their methodology, so we do not know what indicators form their basis, and if non-systemic risks are taken into account. It is possible that these risks are not 
taken into account. Assessments are made with the aid of both international and national scale. Thereat performed analysis has revealed that 48 of 83 constituents of the RF had international ratings (33 constituents in Fitch Ratings, 16 constituents in Standard \& Poor's, 21 constituents in Moody's). But all these ratings are at different days and it is hard to match them. Considerable part (videlicet 35) of constituents of the Russian Federation has not addressed international rating agencies over the last five years, accordingly it is impossible to evaluate their investment attractiveness. Until 2012 rating of a constituent of the RF was valid within one year, but the statute about ratings was altered in 2013, and now rating has to be confirmed on a twice a year basis. We have carried out an analysis of evaluations of credit risks of constituents of the Russian Federation given by international rating agencies. According to evaluation of such international agencies as Fitch Ratings and Moody's such regions as city of Moscow, St. Petersburg, the Republic of Tatarstan, the Republic of Bashkortostan, the Khanty-Mansi Autonomous District are inside the top five of constituents of the Russian Federation with ratings BBB and Baal correspondingly. This rating means that these regions has satisfactory credit worthiness, currently low credit risk expectations, appropriate aptitude to discharge financial obligations in due time. International rating agency Standard \& Poor's gives similar BBB rating to such constituents of the RF as cities of Moscow and St. Petersburg, the Khanty-Mansi Autonomous District, the Republic of Bashkortostan, and the Yamalo-Nenets Autonomous District. Therefore, it may be noted that evaluations of credit risks of constituents of the Russian Federation given by different international rating agencies coincide. Reasons of such coincidence are quote understandable: Moscow and St. Petersburg are Russian financial hubs, the Khanty-Mansi and the Yamalo-Nenets Autonomous Districts are main suppliers of oil and gas for export. The Republics of Tatarstan and Bashkortostan also produce oil, but other industrial fields are developed either.

For the sake of completeness of our research we made analysis of constituents of the Russian Federation included into one of the most developed federal districts of the Russian Federation, namely the Volga Federal District (Table 1).

Table 1. Credit rating of constituents of the Russian Federation included into the Volga Federal District given by international rating agencies*

\begin{tabular}{|l|c|c|l|}
\hline Constituents of the RF & Fitch & Standard and Poors & Moody's \\
\hline Perm Territory & - & - & Withdrawn in 2009 \\
\hline Republic of Bashkortostan & - & BBB-(April, 2013) & Baa3 (June, 2013) \\
\hline Orenburg Region & BB (October, 2012) & - & - \\
\hline Ulyanovsk Region & BB- (November, 2008) & - & - \\
\hline Samara Region & - & BB+ (November, 2013) & Ba1 (July, 2013) \\
\hline Chuvash Republic & BB+ (January, 2014) & - & Ba2 (September, 2013) \\
\hline Udmurt Republic & BB (November, 2013) & - & - \\
\hline Republic of Tatarstan & BBB (January, 2014) & - & Baa3 (November, 2013) \\
\hline Kirov Region & BB- (August, 2013) & - & - \\
\hline Penza Region & BB (September, 2013) & - & - \\
\hline Mari El Republic & BB (November, 2013) & - & - \\
\hline Saratov Region & - & - & Revoked in February, 2013 \\
\hline Republic of Mordovia & - & - & B1 (February, 2013) \\
\hline Nizhni Novgorod Region & BB- (September, 2013) & - & Ba2 (November, 2007) \\
\hline
\end{tabular}

*(the latest date of an update is stated within the brackets)

The table is made according to data from official websites of financial authorities of the RF entities included into the Volga Federal District.

In 2013 only 10 of 14 constituents of the Russian Federation included into the Volga Federal District had international ratings. Four constituents of the RF do not have ratings: the Ulyanovsk Region confirmed its last rating in 2008, the Orenburg Region - in 2012, rating of the Perm Territory was withdrawn in 2009, rating of Saratov region - in February, 2013. That is why we cannot assess credit ratings of these constituents of the RF. Two constituents of the RF - the Republics of Tatarstan and Bashkortostan - have the high credit ratings. Such constituents of the Russian Federation as Kirov, Penza, Samara, Nizhni Novgorod Regions, Republics of Chuvashia, Mordovia and Mari El have BBB rating. This is a speculative rating which means default risk exposure. Thus, it may be noted that considerable part of the Volga Federal District regions are in zone of credit risk.

Russian rating agencies usually make evaluation of economic and social situation or investment attractiveness of regions assigning relevant ratings. Thereat they take into account different indicators including scope and efficiency of economy, budget and social sphere, etc. Rating agencies Expert and NRA make evaluation of investment risks of constituents of the Russian Federation. Thereat only Expert rating agency defines general investment risk per totality of 
social, economic, finance, ecological, criminal and administrative risks. I.e. in this case we can take that non-systemic risks are taken into account when risks are evaluated. Other rating agencies show only a place of a region in attractiveness list, and we do not know what types of risks are taken into account. Constituents of the Russian Federation with the highest ratings of Russian rating agencies at the end of 2012 are presented in Table 2, and constituents of the RF with the lowest ratings are presented in Table 3.

Table 2. Constituents of the Russian Federation with the highest ratings at the end of 2012

\begin{tabular}{|l|c|c|c|c|c|c|c|}
\hline \multicolumn{2}{|c|}{ Expert RA (rating agency) } & \multicolumn{2}{c|}{ RIA-Rating RA } & \multicolumn{2}{c|}{ AC\&M RA } & \multicolumn{2}{c|}{ NRA } \\
\hline Constituents of the RF & Risk & Constituents of the RF & Place & Constituents of the RF & Place & Constituents of the RF & Place \\
\hline Moscow & $1 \mathrm{~A}$ & Moscow & 1 & Moscow & 1 & Moscow & IC1 \\
\hline Moscow Region & $1 \mathrm{~A}$ & St. Petersburg & 2 & Khanty-Mansi AD & 2 & Sakhalin Region & IC1 \\
\hline St. Petersburg & $1 \mathrm{~A}$ & Khanty-Mansi AD & 3 & Nenets AD & 3 & Belgorod Region & IC2 \\
\hline Krasnodar Territory & $1 \mathrm{~A}$ & Tyumen Region & 4 & Yamalo-Nenets AD & 4 & Moscow Region & IC2 \\
\hline Republic of Tatarstan & $1 \mathrm{~A}$ & Moscow Region & 5 & Tyumen Region & 5 & Republic of Tatarstan & IC2 \\
\hline Belgorod Region & 2A & Sverdlovsk Region & 6 & St. Petersburg & 6 & St. Petersburg & IC2 \\
\hline Rostov Region & 2A & Republic of Tatarstan & 7 & Sakhalin Region & 7 & Tyumen Region & IC2 \\
\hline Voronezh Region & $3 \mathrm{~A} 1$ & Yamalo-Nenets AD & 8 & Moscow Region & 8 & Kaliningrad Region & IC3 \\
\hline Lipetsk Region & $3 \mathrm{~A} 1$ & Samara Region & 9 & Perm Territory & 9 & Kaluga Region & IC3 \\
\hline $\begin{array}{l}\text { Tambov Region } \\
\text { Leningrad Region }\end{array}$ & $3 \mathrm{~A} 1$ & Leningrad Region & 10 & Sverdlovsk Region & 10 & Kamchatka Territory & IC3 \\
\hline
\end{tabular}

The table is made according to data from Russian rating agencies [6] - [10].

According to the majority of rating agencies, city of Moscow has the best rating among Russian regions at the end of 2012. As for ratings of other constituents of the Russian Federation, rating agencies do not evaluate them identically. For instance, rating agency Expert made expert evaluation of economic strength and risks for all 83 constituents of the Russian Federation summarizing the results of their activity at the end of 2012. Thereat such constituents of the Russian Federation as Moscow, the Moscow Region, St. Petersburg, the Krasnodar Territory, and the Republic of Tatarstan joined the ranks of regions with maximum potential and minimum risk. Thereat Republics of Ingushetia, Chechnya, and Tyva have low potential and extreme risk. Rating agency RIA-rating makes similar expert evaluation of constituents of the Russian Federation, but situation in this list is somewhat different at the end of 2012. The list is headed by cities of Moscow and St. Petersburg, the Khanty-Mansi Autonomous District, the Tyumen Region, the Moscow Region. The Republic of Tatarstan is only on the seventh place. The Altai Republic (83 place), the Tyva Republic (82 place), the Republic of Ingushetia (81 place) are classified as weak regions.

Table 3. Constituents of the Russian Federation with the lowest ratings at the end of 2012

\begin{tabular}{|c|c|c|c|c|c|c|c|}
\hline \multicolumn{2}{|l|}{ Expert RA (rating agency) } & \multicolumn{2}{|l|}{ RIA-Rating RA } & \multicolumn{2}{|l|}{ AC\&M RA } & \multicolumn{2}{|l|}{ NRA } \\
\hline Constituents of the RF & Risk & Constituents of the RF & Place & Constituents of the RF & Place & Constituents of the RF & Place \\
\hline Tyva Republic & $3 D$ & Altai Republic & 83 & $\begin{array}{c}\text { Republic of North Ossetia- } \\
\text { Alania }\end{array}$ & 83 & Tyva Republic & IC9 \\
\hline Republic of Ingushetia & $3 \mathrm{D}$ & Tyva Republic & 82 & Republic of Mordovia & 82 & Republic of Kalmykia & IC9 \\
\hline Chechen Republic & $3 D$ & Republic of Ingushetia & 81 & Chechen Republic & 81 & $\begin{array}{c}\text { Karachay-Cherkess } \\
\text { Republic } \\
\end{array}$ & IC9 \\
\hline Chukotka AD & $3 \mathrm{C} 2$ & Jewish AD & 80 & Kabardino-Balkar Republic & 80 & $\begin{array}{l}\text { Republic of North Ossetia- } \\
\text { Alania }\end{array}$ & IC8 \\
\hline Jewish AD & $3 \mathrm{C} 2$ & $\begin{array}{c}\text { Republic of North Ossetia- } \\
\text { Alania }\end{array}$ & 79 & Republic of Ingushetia & 79 & Mari El Republic & IC8 \\
\hline Magadan Region & $3 \mathrm{C} 2$ & Kabardino-Balkar Republic & 78 & Altai Republic & 78 & Republic of Ingushetia & IC8 \\
\hline Kamchatka Territory & $3 \mathrm{C} 2$ & Republic of Kalmykia & 77 & Republic of Dagestan & 77 & Kirov Region & IC8 \\
\hline Altai Republic & $3 \mathrm{C} 2$ & $\begin{array}{l}\text { Chechen } \\
\text { Republic }\end{array}$ & 76 & $\begin{array}{c}\text { Karachay-Cherkess } \\
\text { Republic }\end{array}$ & 76 & Kabardino-Balkar Republic & IC8 \\
\hline $\begin{array}{c}\text { Republic of North Ossetia- } \\
\text { Alania }\end{array}$ & $3 \mathrm{C} 2$ & Chukotka AD & 75 & Tyva Republic & 75 & Zabaykalsky Territory & IC8 \\
\hline $\begin{array}{c}\text { Kabardino-Balkar Republic; } \\
\text { Karachay-Cherkess } \\
\text { Republic; } \\
\text { Republic of Kalmykia } \\
\end{array}$ & $3 \mathrm{C} 2$ & $\begin{array}{c}\text { Karachay-Cherkess } \\
\text { Republic }\end{array}$ & 74 & Kostroma Region & 74 & Chechen Republic & IC7 \\
\hline
\end{tabular}

The table is made according to data from Russian rating agencies [6] - [10]. 
Rating agency AC\&M in spite of Moscow includes the Khanty-Mansi Autonomous District, the Nenets Autonomous District, the Yamalo-Nenets Autonomous District, and the Tyumen Region into top five. Republics of Altai (83 place), Tyva (82 place), Ingushetia (81 place), the Jewish Autonomous Region (80 place), the Republic of North Ossetia-Alania (79 place) are classified as the weakest regions. Rating agency NRA in spite of Moscow includes the Sakhalin Region (with rating similar to Moscow), the Belgorod Region, the Moscow Region, and the Republic of Tatarstan into top five. Republics of Tyva, Kalmykia, Karachay-Cherkess, North Ossetia-Alania, and Mari El are classified as the weakest regions. Therefore, expert evaluation of constituents of the Russian Federation made by Russian expert agencies differs. Reason of such evaluation diversity lies in their methodologies which in most cases are not disclosed.

To make the picture complete we carried out more detailed analysis of ratings and risks of constituents of the Russian Federation included into the Volga Federal District (Table 4).

Table 4. Rating of constituents of the Russian Federation included into the Volga Federal District given by Russian rating agencies at the end of 2012

\begin{tabular}{|c|c|c|c|c|}
\hline Constituents of the RF & Expert RA (rating agency) & RIA-Rating RA & AC\&M RA & NRA \\
\hline Perm Territory & $2 \mathrm{~B}$ & 11 & 9 & IC4 \\
\hline Republic of Bashkortostan & $2 \mathrm{~B}$ & 13 & 12 & IC4 \\
\hline Orenburg Region & 3B1 & 22 & 25 & IC4 \\
\hline Ulyanovsk Region & 3B1 & 46 & 41 & IC5 \\
\hline Samara Region & $2 B$ & 9 & 14 & $\mathrm{IC} 3$ \\
\hline Chuvash Republic & 3B1 & 51 & 54 & IC6 \\
\hline Udmurt Republic & 3B1 & 44 & 44 & IC5 \\
\hline Republic of Tatarstan & $1 \mathrm{~A}$ & 7 & 23 & $\mathrm{IC} 2$ \\
\hline Kirov Region & 3B1 & 58 & 57 & $\mathrm{IC} 8$ \\
\hline Penza Region & 3B1 & 57 & 71 & IC6 \\
\hline Mari El Republic & $3 \mathrm{~B} 2$ & 71 & 73 & $\mathrm{IC} 8$ \\
\hline Saratov Region & 3B1 & 43 & 61 & IC5 \\
\hline Republic of Mordovia & $3 \mathrm{~B} 2$ & 66 & 82 & IC6 \\
\hline Nizhni Novgorod Region & $2 \mathrm{~B}$ & 17 & 31 & IC4 \\
\hline
\end{tabular}

The table is made according to data from Russian rating agencies [6] - [10].

The study has revealed that Expert, NRA and RIA-Rating assigned minimum risk to the Republic of Tatarstan at the end of 2012, though AC\&M rating agency assigned just the third place to the Republic of Tatarstan. Per totality of ratings (3 of 4) the second place belongs to the Samara Region, and the third place belongs to the Republic of Bashkortostan. Therefore, it is important to note that Russian rating agencies assign quite high rating to the Perm Territory, though it does not have rating from international rating agencies. Therefore, AC\&M rating agency gives it the 9th place which is above the Republic of Tatarstan, the Samara Region, and the Republic of Bashkortostan. According to the data of Expert rating agency, the highest investments risk is observed in the Mari El Republic and the Republic of Mordovia (3B2), and according to data of NRA rating agency - the Kirov Region and the Mari El Republic (IC8). In the rating of RIA-Rating last places belong to the Mari El Republic (71), the Republic of Mordovia (66), and the Kirov region (58), and in the rating of AC\&M - the Republic of Mordovia (82), the Mari El Republic (73), and the Penza Region (71). Conclusion concerning investment attractiveness and risks of the Volga Federal District regions is obvious. Both international and Russian rating agencies acknowledge that two constituents of the RF, namely the Republic of Tatarstan and the Republic of Bashkortostan, are the most attractive and the least risk-related. Russian rating agencies acknowledge that Republics of Mari El and Mordovia are the least attractive regions.

In the process of evaluation of investment attractiveness and risks of regions, investors may use ratings of the Ministry of Regional Development of the Russian Federation. Every year the Ministry estimates summary index of economic and social situation of regions. At that, development of the real sector of economy, investment attractiveness, incomes and employment of population, indicators of budgetary system of a region are evaluated. According to the evaluation of the Ministry of Regional Development of the RF for 2012, the Tyumen Region, the Khanty-Mansi Autonomous District, the Yamalo-Nenets Autonomous District, the Sakhalin Region, the city of Moscow are included into top five. The Republic of Altai (83), the Altai Territory (82), the Republic of North Ossetia-Alania (81), the Ivanov Region (82), the Kurgan Region (79) are included into last five places. The Ministry of Regional Development of the Russian Federation evaluates regions by also their investment attractiveness. This rating differs from general rating of economic 
and social situation of Russian regions. The rating of investment attractiveness is estimated on the basis of such indicators as construction, construction growth rate, accommodation deployment, investments into nominal capital, proportion of profit-making companies. Such regions as the Tyumen District, the Krasnodar Territory, the Khanty-Mansi Autonomous District, the Leningrad Region, and the Nenets Autonomous District are in the top five of this rating. The Ivanov Region (83), the Republic of North Ossetia-Alania (82), the Chechen Republic (81), the Kurgan Region (80), the Republic of Tyva (79) are included into last five places. Comparison of two abovementioned ratings gives evidence that rating of evaluation of economic and social situation and rating of investment attractiveness slightly differ. The Tyumen Region and the Khanty-Mansi Autonomous District are in the top five of both ratings. The Republic of North OssetiaAlania, the Ivanov Region, and the Kurgan Region are also included into last five places in both ratings. Moreover these ratings do not coincide with ratings of some Russian rating agencies. Certainly, this divergence is connected with divergence in evaluation methodology. But in contradistinction to rating agencies, the Ministry of Regional Development of the Russian Federation discloses its rating methodology. Analysis of methodology of making of summary index of economic and social situation and rating of investment attractiveness of regions has revealed that there are not any indicators characterizing non-systemic risks. These are risks considering management quality in a region. We suppose that these indicators shall be also evaluated. In that vein we note that annual evaluation of regional finance management quality published by the Ministry of Finance of the Russian Federation is of interest. The Ministry of Finance of the Russian Federation divides all constituents of the Russian Federation into three groups. These are regions with:

- $\quad$ high regional finance management quality;

- proper regional finance management quality;

- bad regional finance management quality.

There are 23 constituents of the Russian Federation in the first group, 54 constituents in the second group, 6 constituents in the third group. What's interesting is that regions, which were in the last five in all ratings, are in the first group with high regional finance management quality. They are, for instance, the Kurgan Region, the Republic of Tyva, the Altai Republic, the Altai Territory. At the same time constituents of the RF, which are among last constituents in other ratings, are in the group with bad regional finance management quality: the Republic of North Ossetia-Alania, the Republic of Mordovia, the Republic of Ingushetia. Of course we understand that this evaluation is single-ended and connected with evaluation of activities of financial authorities of constituents of the Russian Federation. In this evaluation they used following 7 criteria: budget planning, budget execution, debt management, financial arrangements with municipal units, government property management and state service delivery, budget process accountability, as well as indicators characterizing execution of Russian Federation Presidential Decrees dated May 7, 2012. To our opinion, there are criteria referring to evaluation of systemic and non-systemic risks and at the same time to the budget sphere in this evaluation system. These rating may be useful for investors in evaluation of their risks, especially in case of investment in publicly owned projects.

\section{Conclusion}

Having analyzed various evaluations of credit risks, economic and social situations, investment attractiveness of constituents of the Russian Federation made by international and Russian rating agencies, the Ministry of Regional Development of the Russian Federation, the Ministry of Finance of the Russian Federation, it can be noted that ratings differ. It is conditioned by differences in their methodologies. But as a rule rating agencies do not disclose their methodologies. Nevertheless, speak by disclosed information, indicators of regions dependence on business cycle revenues, activeness and participation in co-financing program, amount of public investments are not taken into account in evaluation of regions. On the one hand business cycle revenues provide advantages to constituents of the Russian Federation which have such revenues. For example, only 3 of 14 constituents of the Russian Federation in the Volga Federal District have business cycle revenues, and these regions are the Republic of Tatarstan, the Republic of Bashkortostan, and the Samara Region. These revenues are connected with oil and gas component of their economies. It explains their high rating just as among constituents of the district so generally in the Russian Federation. But along with this it shall be understood that their business cycle risks are higher. We also suppose that in the process of evaluation of risks of regions we shall take into account investment activity of public authorities in the context of their participation in different investment projects on co-financing programs. Besides, rating agencies generally use indicators of investment amount in their evaluation. But we suppose that indicators of amount of public investments including investments from own funds are of interest for evaluation of non-systemic risks.

The fundamental problem of Russian regions lies in lack of concern in increasing their capabilities for attraction of investors into regions. Participation in co-financing programs, amounts of public capital contributions from own funds give 
evidence of regional authority's active stand in enhancement its investment climate. Although a requirement for participation in co-financing programs is availability of own financial resources, and many constituent of the RF do not have them. And when investors select a region for investment, they have to take into account all ratings, as international, so Russian rating agencies, despite of their sometimes different evaluation.

\section{References}

Hommel U., M. Frenkel, M. Rudolf, 2005. Risk Management: Challenge and Opportunity. - Second Revised and Enlarged Edition, p.838.

Paudyn, B., August 2013. Credit rating agencies and the sovereign debt crisis: Performing the politics of creditworthiness through risk and uncertainty. Review of International Political Economy, 4: 788-818.

Li, C., C. Balding and M. Lee, May 2013. Sovereign risk, elections, and contagion. ADB Economics Working Paper Series: 1-20.

Arnold, B., C. Borio, L. Ellis and F. Moshirian, December 2012. Systemic risk, macroprudential policy frameworks, monitoring financial systems and the evolution of capital adequacy. Journal of Banking and Finance, 12: 3125-3132.

Richard A. Musgrave, P. Musgrave, 1973. Public Finance in Theory and Practice, p.778.

Official website of rating agency Expert RA. Date Views 15.01.2014 www.raexpert.ru

Official website of rating agency RIA Rating. Date Views 15.01.2014 www.riarating.ru

Official website of rating agency AC\&M. Date Views 15.01.2014 www.akmrating.ru

Official website of rating agency (NRA). Date Views 15.01 .2014 www.ra-national.ru

Official website of the Ministry of Finance of the Russian Federation. Date Views 15.01.2014 www.info.minfin.ru

Danielsson J and Shin HS (2002). Endogenous Risk, 21 September. Available at: http://www.ucd.ie/t4cms/DANIELSSON.pdf.

Grigoreva E. and Fesina E. Economic Security as a Condition of Institutional Support of Economy Modernization // World Applied Sciences Journal, 2014, 31 (5). P. 940-948.

Morris S and Shin HS (2003). Liquidity black holes. Cowles Foundation Discussion Paper No.1434, Cowles Foundation for Research in Economics, Yale University, New Haven, CT, September.

Danielsson J (2002). The emperor has no clothes: Limits to risk modelling. Journal of Banking \& Finance, 26: 1273-1296, July.

Grauwe P (2007). The hard task of pricing liquidity risk. EconoMonitor, 17 December. Available at: http://www.economonitor.com /blog/2007/12/the-hard-taskof- pricing-liquidity-risk/.

Persaud A (2008). How risk sensitivity led to the greatest financial crisis of modern times, 7 October. Available at: http://www.voxeu. org/index.php?q=node/ 2101. 